\title{
RELATIONS BETWEEN PEGMATITE EMPLACEMENTS AND TECTONO-METAMORPHIC EVENTS IN THE SERIDÓ GROUP, NORTHEASTERN BRAZIL
}

\author{
VISHWAMBHAR N. AGRAWAL*
}

\begin{abstract}
RESUMO RELAÇÕES ENTRE POSICIONAMENTOS DE PEGMATITOS E EVENTOS TECTONOMETAMÓRFICOS NO GRUPO SERIDÓ, NORDESTE DO BRASIL. As relações de idade dos pegmatites com as fases de dobramentos regionais $\left(F_{2}\right.$ e $\left.F_{3}\right)$ e suas feições estruturais sugerem a existência de duas suites distintas destes corpos no Grupo Seridó: uma suíte mais antiga (pré- $\mathrm{F}_{3}$ ) de pegmatitos intensamente deformados, apresentando, localmente, tramas tectônicas relacionadas a $\mathrm{F}_{2} \mathrm{e} / \mathrm{ou} \mathrm{F}_{3}$ e outra mais nova (tarde após $\mathrm{F}_{3}$ ) compreendendo corpos pouco deformados ou não-deformados e sem qualquer trama tectônica. A maior concentração de pegmatitos, incluindo os membros de ambas as suítes, ocorre em metassedimentos de médio aalto grau, na parte leste dafaixaSeridó. As estruturas e tramas tectônicas encontradas nos pegmatitos da suíte mais antiga mostram que seu posicionamento teve início durante o evento tectono-metamórfico regional $\mathrm{F}_{2}$ e terminou antes de F?. As relações estruturais dos pegmatitos da suíte mais nova, e a ausência, nestes corpos, de tramas planares e lineares, sugerem que os mesmos foram posicionados posteriormente à fase de cristal ização/recristalizaçãosintectônicarelacionadaao evento tectono-metamórfico regional $\mathrm{F}_{3}$. As idades de dois pegmatitos da suíte mais nova estão situadas entre 510 a $450 \mathrm{Ma}$, o que indica uma idade tardibrasilianaparaasua colocação. Estasuítepegmatíticaparece ser graniticamenterelacionadaagranitos brasilianos tarditectônicos (com idades de 570 a $510 \mathrm{Ma}$ ). Não é possível estabelecer no presente a idade da suíte mais antiga, assim como sua relação com os granitos,por falta de dados geocronológicos e geoquímicos. Contudo, não há dúvida que seu posicionamento ocorreu cedo na históriatectono-metamórfica do Grupo Seridó.
\end{abstract}

Palavras-chaves: Suítes de pegmatitos, episódios de posicionamento de pegmatitos, fases de dobramento, eventos metamórficos, magmatismo granitóide, Grupo Seridó, Nordeste brasileiro.

\begin{abstract}
The age relationships of pegmatites to the regionally important folding phases $\left(\mathrm{F}_{2}\right.$ and $\left.\mathrm{F}_{3}\right)$ and their deformation features suggest the existence of two distinct suites of pegmatites in the Seridó Group: an older (pre- $\left.\mathrm{F}_{3}\right)$ suite ofhighly deformed pegmatites showing, locally, tectonic fabrics related to $F_{2}$ and/or $F_{3}$; and a younger (late-post $F_{3}$ ) suite of weakly deformed or undeformed pegmatites without any tectonic fabric. The major concentration of pegmatites, including members of both the suites, occurs within medium - to high-grade metasediments in the eastern part of the Seridó belt. The tectonic structures and fabrics found in pegmatites of the older suite show that their emplacement began during the regional $F_{2}$ tectono-metamorphic event and outlasted it. The structural relationships of pegmatites of the younger suite, together with their lackof planar and linear fabrics, suggest that their emplacement post-dates the phase of syntecton ic crystal 1 ization/recry stal 1 ization related to the regional $\mathrm{F}_{3}$ tectono-metamorphic event. The ages obtained for two pegmatites of the younger suite are situated between 510 and $450 \mathrm{Ma}$, which suggests a late Brasil iano age for its emplacement. This pegmatite suite appears to be genetically related to the late-tectonic (570-510 Maold) Brasiliano granites. The age of the older pegmatite suite, as also its relationship with the granites, cannot be established at present for lack of geochronological and geochemical data. However, there is no doubt that its emplacement occurred early in the tectono-metamorphic history of the Seridó Group.
\end{abstract}

Keywords: Pegmatite suites, pegmatite emplacement episodes, folding phases, metamorphic events, granitoid magmatism, Seridó Group,Northearstern Brazil.

INTRODUCTION It is known from the previous studies that the Proterozoic supracrustal rocks of the Seridó group, occupying a large area in the state of Paraíba and Rio Grande do Norte, have a polyphase structural and metamorphic history. Their tectono-metamorphic evolution has involved at least five phases of deformation $\left(\mathrm{Fi}-\mathrm{F}_{5}\right)$, accompanied by low to intermediate pressure type metamorphism varying from amphibolite to green-schist facies (Mello \& Mello 1974, Salim et al. 1979, Martins Sá \& Legrand 1983, Jardim de Sá 1984). The metamorphic grade in general increases from west to east across the supracrustal belt (Mello \& Mello 1974). In the larges areas of the northeastern part of the belt, Salim et al. (1979) and Martins Sá \& Legrand (1983) have defined a succession of metamorphic phases roughly synchronous with deformation phases. Their results show that the climax of regional metamorphism occurred during $\mathrm{F}_{2}$, attaining the amphibolite facies at the anatexis isograd, and was marked by the formation of such minerals as cordierite, sillimanite and diopside, and of migmatites. Lima (1987) has carried out a regional study of the metamorphic history of the supracrustal rocks and has recognized two major metamorphic events, broadly synchronous with respectively $\mathrm{F}_{2}$ and $\mathrm{F}_{3}$ deformations and ranging in grade from lower to upper amphibolite facies. His results show that P-T conditions during the second event increased from west to east, reaching a maximum in the central part of the belt, and that the metamorphic grade during this event attained the sillimanite isograd. In his view the mineral assemblages which crystallized during the first metamorphic event have undergone a partial to total reequilibration during the second event. The Seridó supracrustal sequence is intruded by a huge volume of granitic rocks. These have been ascribed to more then three periods of emplacement by Jardim de Sá et al. (1981). Rb-Sr and U-Pb ages of different suites of granites have been interpreted by Macedo et al. (1984), Jardim de Sá et al. (1988) and Bertrand \& Jardim de Sá (1990) to show that the Seridó supracrustal rocks have a polycyclic history, having been deformed and metamorphosed during the Transamazonian orogeny before being affected by the Brasiliano deformation and metamorphism. This view is contested by other workers who 
favour the idea of a monocyclic (Brasiliano) evolution for the Seridó supracrustal belt (Caby \& Arthaud 1986, Caby et al. 1987, Caby 1989).

Besides granites, a large number of granitic pegmatites, both homogeneous and heterogeneous (with internal zoning), is associated with the Serido supracrustal rocks. They are composed of essentially muscovite, quartz and microcline, and show a variable degree of albitization. A majority of these bodies is mineralized and has yielded thousands of tons of valuable minerals such as beryl, columbite-tantalite, cassiterite, spodumene and others since the beginning of the Second World War. Owing to the occurrence of tin-bearing pegmatites in this region (also known as Borborema Pegmatite Province), the same has been included by Schuiling (1967) in his "tin belt" which extends from Rio Grande do Sul up to Ceará and Rio Grande do Norte in eastern Brazil, and which continues into Nigeria and Hoggar on the African side. The age(s) of emplacement of pegmatites and their relationships to the tectonothermal events in the Seridó Group have not been established yet. Only six pegmatites have been dated so far (Marble 1949, Dirac\& Ebert 1967, Almeida et al. 1968, Ebert 1969). The ages for five of them are situated between 550 and $450 \mathrm{Ma}$. The age obtained for the sixth pegmatite is $780 \mathrm{Ma}$. These age data have been interpreted by previous workers as suggesting a late to post-tectonic (Brasiliano) age for the pegmatites in general, Almeida et al. 1968, Brito Neves et al. 1974, Pessoa 1974, Galindo 1981, Brito Neves 1983, Jardim de Sá 1984). A recent study (Agrawal 1986) of the relationships of pegmatites to the structural sequence has, however, revealed more than one period of pegmatite emplacement in the Serido supracrustal belt. The aim of the present paper is to discuss the relations of pegmatite emplacement episodes and the tectonometamorphic events in this belt.

\section{AGE RELATIONSHIPS OF PEGMATITES TO THE} REGIONALLY IMPORTANT FOLDING PHASES A

study of the relationships of pegmatites to mesoscopic structural elements of the enclosing rocks (Seridó group) was carried out in the eastern part of the Seridó belt (between $36^{\circ}$ and $37^{\circ} \mathrm{W}$ long, and $6^{\circ}$ and $7^{\circ} \mathrm{S}$ lat.), particularly in the municipalities of Juazeirinho - PB, Pedra Lavrada - PB, Nova Palmeira - PB, Picuí - PB, Frei Martinho - PB, Acarí - RN, Carnaúba dos Dantas - RN, Parelhas - RN and Junco do Seridó - PB which together cover the area of the major concentration of pegmatites (Fig. 1). In the area studied he pegmatites mostly occur within garnet-biotite schists (with or without cordierite and andalusite/sillimanite) of the Seridó formation or within the micaceous quartzites of the Equador formation. The mesoscopic structures developed in these rocks correspond to $\mathrm{Fi}, \mathrm{F}_{2}, \mathrm{~F}_{3}$ and $\mathrm{F}_{5}$ structures of the regional structural sequence proposed by Jardim de Sá (1984). On the basis of their relationships to the structural elements representing regionally important folding phases $\left(\mathrm{F}_{2}\right.$ and $\left.\mathrm{F}_{3}\right)$, it is possible to divide the pegmatites into following four groups:

1. Pegmatites wh ich are concordant with the principal foliation $\left(\mathrm{S}_{2}\right)$ and are deformed by $\mathrm{F}_{3}$ folds (subgroup 1 of Agrawal 1986).

2. Pegmatites which cut the principal foliation $\left(\mathrm{S}_{2}\right)$ and the intrafolial $\mathrm{F}_{2}$ folds but which are folded by $\mathrm{F}_{3}$ folds (subgroup 2 of Agrawal 1986).

1. Pegmatites which cut the principal foliation $\left(\mathrm{S}_{2}\right)$ and the $\mathrm{F}_{2}$ folds which appear to follow the axial plane of $F_{3}$ folds.

3. Pegmatites which cut $\mathrm{F}_{3}$ folds.

From their age relationships to $F_{2}$ and $F_{3}$ folds, it is clear that the pegmatites of the Serido Group occupy more than one position on the structural time scale (Fig. 2). They also differ markedly in the intensity of their deformation, pegmatites of group 1 and 2 being far more deformed than those of group 3 and 4. Group 1 pegmatits, which are concordant with $\mathrm{S}_{2}$, commonly show development of pinch-and-swell and

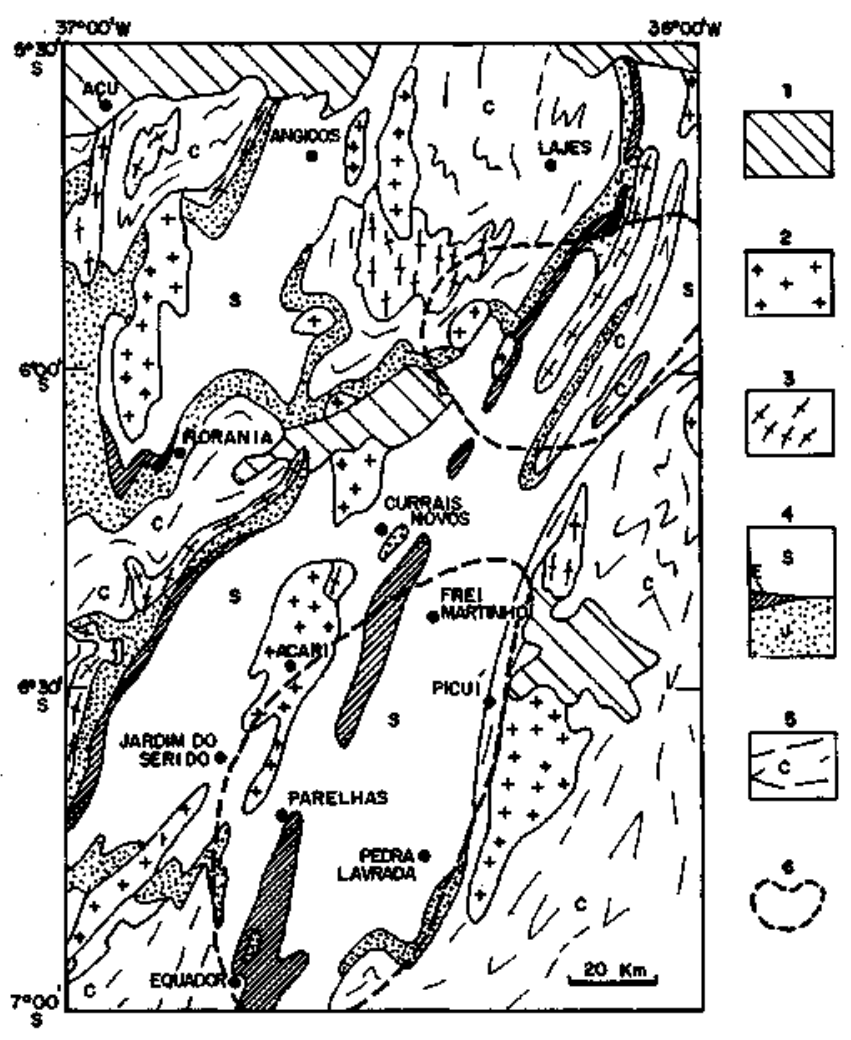

Figura 1 - Esboço geológico da porção oriental da faixa Seridó, Rio Grande do Norte e Paraíba (adaptado e modificado de Leterrier et al. 1990) mostrando a localização das áreas ricas em pegmatitos: 1. cobertura mesozóicacenozóica; 2. granitos brasilianos; 3. ortognaisses transamazônicos; 4. Grupo Seridó (Proterozóico Inferior), compreendendo as Formações Jucurutu (J), Equador (E) e Seridó (S); 5. Complexo Caicó (Arqueano-Proterozóico Inferior); 6. áreas ricas em pegmatitos Figure 1 - Geological sketch map of the eastern part of the Seridó belt, Rio Grande do Norte and Paraíba (adapted and modified from Leterrier $e t$ al. 1990) showing the locations of the pegmatite-rich areas: 1. MesozoicCenozoic cover; 2. Brasiliano granites; 3. Transamazonian orthogneisses; 4. Early Proterozoic Seridó Group, comprising the Jucurutu (J), Equador (E) and Seridó (S) formations; 5. Archean to Early Proterozoic Caicó Complex; 6. pegmatite-rich areas

boudinage structures. They locally show development of a planar fabric parallel to $S_{2}$ and are folded by $F_{3}$ and later folds. Group 2 pegmatites, which cut $F_{2}$ folds but which are folded by $F_{3}$, locally show development of a coarse foliation $\left(S_{3}\right)$ parallel to the $\mathrm{F}_{3}$ axial plane. This foliation is defined by a preferred dimensional orientation of quartz, feldspar and mica. In some cases a mineral lineation related to $F_{3}$ is also developed, defined variably by aggregates of such minerals as quartz, feldspars, garnet and sillimanite. In contrast, the pegmatites of group 3 and 4 generally occur as weakly deformed (or undeformed) tabular bodies which do not show any tectonic fabric $\left(\mathrm{F}_{2}\right.$ or $\left.\mathrm{F}_{3}\right)$. The only evidence of deformation found in them is fracturing.

On deformation criteria it is possible to distinguish two distinct suites of pegmatites in the Seridó Group: 1. an older suite of highly deformed pegmatites with some kind of tectonic favric (groups 1 and 2); and 2. a younger suite of weakly deformed or undeformed pegmatites without any tectonic fabric (groups 3 and 4). The pegmatites of the older suite predate the regional $\mathrm{F}_{3}$. The structural features present in them suggest that their emplacement began sometime during the $\mathrm{F}_{2}$ fold phase and ended before the incidence of $\mathrm{F}_{3}$ folding. The emplacement of the younger suite seems to have 


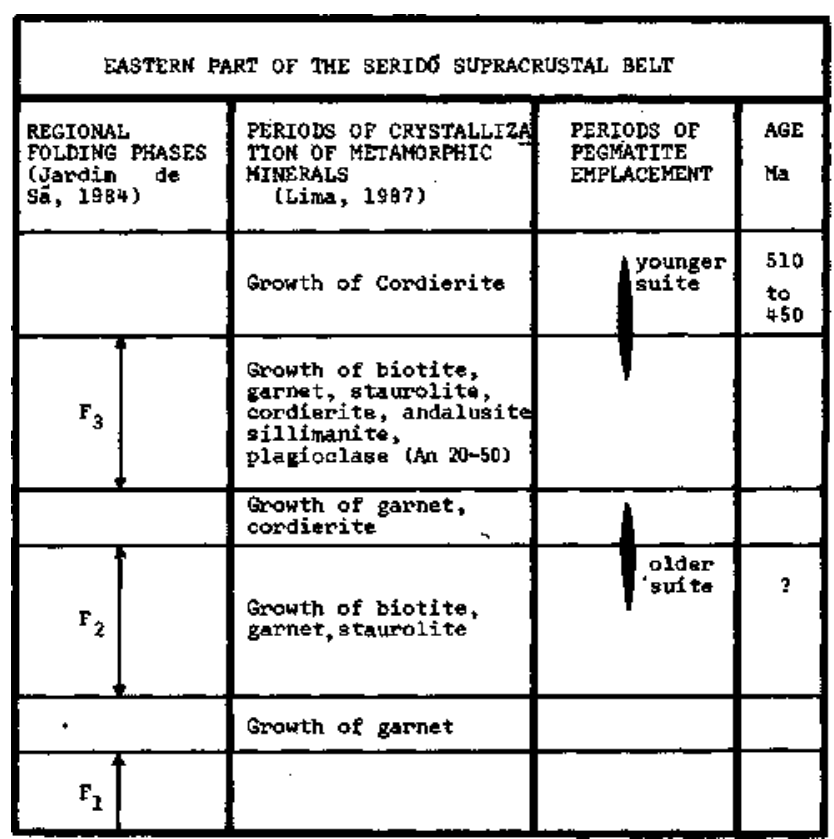

Figura 2 - Período de posicionamento de pegmatitos em relação às fases de dobramentos regionais e episódios metamórficos no Grupo Seridó

Figure 2 - Periods of pegmatite emplacement in relation to regional folding phases and metamorphic episodes in the Seridó Group

begun in the last stages of the $\mathrm{F}_{3}$ fold phase and to have outlasted it.

\section{AGES OF PEGMATITE EMPLACEMENT EPISODES}

Very few (about six) pegmatites have been dated so far from the Seridó belt. Among them, the structural relationships of only two pegmatites are clearly defined. These are: 1 . Also Seridozinho in Juazeirinho - PB and 2. Alto Boqueirão in Parelhas - RN. Their ages, obtained from six K-Ar muscovite analyses, two U-Pb uraninite analyses and one $\mathrm{Rb}-\mathrm{Sr}$ muscovite analysis, are situated between 510 and $450 \mathrm{Ma}$ (Marble 1949, Dirac \& Ebert 1967, Almeida et al 1968, Ebert 1969). Both these pegmatites are weakly deformed with development of fractures but without any tectonic fabric. Alto Seridozinho cuts $F_{2}$ folds and appears to follow the axial plane of $F_{3}$ (group 3 ). Alto Boqueirão appears to post-date the $\mathrm{F}_{3}$ folds (group 4). Their ages thus suggest a late Brasiliano age for the episode of emplacement of the younger suite of pegmatites in the Seridó Group. As regards the older ( $\mathrm{pre}^{-\mathrm{F}_{3}}$ ) suite of pegmatites (group 1 and 2), no geochronological data are available on them at the moment. However, a rough age for the emplacement of concordant pegmatites (group 1) can be inferred from the age of $\mathrm{F}_{2}$ deformation event. Macedo etal. (1984) and Jardim de Sá et al. (1 988) have interpreted the Rb-Sr whole rock ages $(2.0-1.9 \mathrm{Ga})$ of granite augen gneisses, which they regard as syntectonic intrusions, as indicative of a Transamazonian age for the regional $\mathrm{F}_{2}$. As concordant pegmatites, lying parallel to the $S_{2}$ foliation, show evidence of extension in this plane and development, locally, of $F_{2}$ fabric, it follows that their emplacement should date back to Transamazonian time, if that age is accepted for the regional $F_{2}$. In the absence of geochronological date on the older suite of pegmatites, however, it is not possible at present to establish a precise age for their emplacement or the time interval separating them from the younger suite.

\section{RELATIONSHIPS OF PEGMATITES WITH METAMORPHISM AND GRANITOID MAGMATISM}

The major concentration of both the older (groups 1 and 2) and the younger suite (groups 3 and 4) of pegmatites occurs within medium- to high-grade metasediments in the eastern part of the Seridó supracrustal belt. Two main events of regional metamorphism, broadly synchronous with, respectively, $F_{2}$ and $\mathrm{F}_{3}$ deformations, have been identified in this belt by Lima (1987). His results show that the metamorphic grade during these events varied from lower to upper amphibolite facies in the main pegmatite field. The parallelism of group 1 pegmatites with $\mathrm{S}_{2}$ (i.e. axial plane of $\mathrm{F}_{2}$ ), together with their locally developed planar fabric lying in the same plane, show that their emplacement occurred during the $\mathrm{F}_{2}$ tectonometamorphic event. On the other hand, the cross-cutting relationship of group 2 pegmatites with $F_{2}$ structures and the evidence of their deformation and recrystallization during the $\mathrm{F}_{3}$ tectono-metamorphic event suggest that their emplacement began after the $F_{2}$ tectono-metamorphic event and ended before $\mathrm{F}_{3}$. Thus, considering the older suite of pegmatites as a whole, its emplacement seems to be syn- to post-tectonic in relation to the regional $\mathrm{F}_{2}$ tectono-metamorphic event (Fig. 2). Salim et al. (1979) and Martins Sá \& Legrand (1983) have shown that the regional metamorphism during $\mathrm{F}_{2}$ attained the anatexis isograd in the northeastern part of the Seridó belt and was accompanied by the formation of migmatites. It is therefore possible thatsome of the older pegmatites, especially the concordant (group 1) pegmatites associated with the highgrade schists, are the product of regional metamorphism. The structural relationships of pegmatites of the younger suite, together with their lack of planar and linear fabrics, suggest that their emplacement post-dates the phase of syntectonic crystallization/recrystallization related to the regional $\mathrm{F}_{3}$ tectono-metamorphic event (Fig. 2).

The ages obtained for the pegmatites of the younger suite, bearing $\mathrm{Nb}-\mathrm{Ta}$-Sn-Li mineralization, are situated between 510 and 450 Ma (Marble 1949, Dirac \& Ebert 1967, Almeida etal. 1968, Ebert 1969), whereas the late-tectonic Brasiliano granitic intrusions have been dated between 570 and $510 \mathrm{Ma}$ (Jardim de Sá et al. 1988). This seems to suggest that the emplacement of the younger suite of pegmatites closely followed that of the late-tectonic granites. It is possible that the two are genetically related. In the Pan-African belt of the Hoggar-Nigeria shields, which is considered to be the continuation of the Brasiliano erogenic belt of northeast Brazil (Torquato\&Cordani 1981,Lesquer et al. 1984, Porada 1989, Caby 1989, Bertrand \& Jardim de Sá 1990) and where granitic pegmatites carrying the $\mathrm{Sn}-\mathrm{Nb}$-Ta mineralization also occur, the trace-element chemistry of muscovites from the latter and the associated granites have been studied by Kilster (1990). He has presented data to show that the latetectonic (550 Ma old) Pan-African granites (the leucogranites, are the parental sources of 530 Ma old pegmatites bearing the $\mathrm{Sn}-\mathrm{Nb}$-Ta mineralization. It seems very likely that the younger suite of the Serido pegmatites is similarly related to the latetectonic Brasiliano granites. However, their exact relationship needs to be identified through a detailed geochemical investigation. As regards the older suite of Seridó pegmatites, neither geochronological nor geochemical data are available on them. It is therefore not possible at this stage to assess their relationships with the granites.

CONCLUSIONS On structural criteria, two suites of pegmatites can be distinguished in the Seridó Group: an older $\left(\right.$ pre- $\left.\mathrm{F}_{3}\right)$ suite of highly deformed pegmatites with locally developed planar and linear fabrics related to $\mathrm{F}_{2}$ and/or $\mathrm{F}_{3}$; and a younger (late-post $\mathrm{F}_{3}$ ) suite of weakly deformed or undeformed pegmatites without any tectonic fabric.

From the structural relationships of pegmatites and the tectonic fabrics found in them it appears that the emplacement of the older suite is syn- to post-tectonic in relation to the regional $\mathrm{F}_{2}$ tectono-metamorphic event, whereas that of the younger suite post-dates the phase of syntectonic mineral growth related to the regional $\mathrm{F}_{3}$ tectono-metamorphic event. 
The younger (roughly 510-450 Ma old) suite of pegmatites is of a late Brasiliano age and is probably genetically related to the late-tectonic (570-510 Ma old) Brasiliano granites. The age of the older pegmatite suite, as also its relationship with the granites, cannot be established at present for lack of geochronological and geochemical data, but there is no doubt that its emplacement occurred early in the tectonometamorphic history of the Seridó supracrustal rocks.

A radiometric dating of different groups (1-4) of the ages of their emplacement, and can also be useful in establishing the ages of the tectono-metamorphic events in the Seridó Group. In the Moines of Scotland, for example, a Precambrian orogeny (the Morarian) has been established on the basis of the radiometric ages of pegmatites with known structural relationships (Van Breemen et al. 1974, Piasecki \& Van Breemen 1979, Piasecki et al. 1981).

Acknowledgements The author thanks CNPq (Conselho Nacional de Desenvolvimento Científico e Tecnológico Brazil) for providing a research grant for carrying out this study.

\section{REFERENCES}

AGRA W AL, V.N. 1986. Structural evidence for an early episode of pegmatite emplacement in the Seridó Group. In: SIMP. GEOL. NORDESTE, 12. João Pessoa, 1986. Atas... João Pessoa, SBG. p. 282-289.

ALMEIDA,F.F.M.;MELCHER,G.C.;CORDANI,U.G.;KAWASHITA,K.; VANDOROS, P. 1968. Radiometric age determinations from Northern Brazil. Boi. Soe. Brás. Geol., 17(1):3-14.

BERTRAND, J.M. \& JARDIM DE SA, E.F. 1990. Where are the Eburnian Transamazonian collisional belts? Can. J. Earth Sei., 27:1382-1393.

BR1TONEVES, B.B. 1983. Mapa Geológico do Nordeste Oriental do Brasil, Escala l/J 000.000. São Paulo 117 p. (Tese de Livre-Docência, IG/USP).

BRITO NEVES,B.B.;VANDOROS,P.;PESSOA,D.A.R.;CORDANI,U.G. 1974. Reavaliação dos dados geocronológicos do Pré-Cambriano do Nordeste brasileiro. In: CONOR. BRAS. GEOL, 28. Porto Alegre, 1974. Anais... Porto Alegre, SBG. p. 261 -271.

CABY, R. 1989. Precambrian terranes of Benin-Nigeria and northeast Brazil and the late Proterozoic South Atlantic fit. Geol. Soc. Am. Bull., 230:145158. (Spec. Pap.).

CABY, R. \& ARTHAUD, M. 1986. Major Precambrian nappesofthe Brasiliano belt, Ceará, northeast Brazil. Geology, 14:871 -874

CABY, R.; RAHAMAN, M.A.;BOESSE, J.M. 1987. Archaean and Proterozoic of Southwest Nigeria: lithostratigraphy and petrostructural evolution compared with the Saharan and Brazilian Segments. In: COL. AFRICAN GEOLOGY, H.Berlin, 1987.Abstracts... Berlin

DIRAC, P.M. \& EBERT, H. 1967. Isotopic ages from the pegmatite province of Eastern Brazil. Nature, 215:948-949.

EBERT, H. 1969. Geologia do Alto Seridó, nota explicativa e folha geológica de Currais Novos. Recife, SUDENE. 120 p. (Série Geologia Regional 11).

GALINDO, A.C. 1981. Geocronologia do Pré-Cambriano do Rio Grande do Norte. Boi. Dep. Geol. UFRN, 1:20-35.

JARDIM DE SÁ, E.F. 1984. Geologia da região do Seridó: reavaliação de dados. In: SIMP. GEOL. NORDESTE, 11. Natal, 1984. Atas... Natal, SBG. p. 278-296.

JARDIMDESÁ, E.F.; LEGRAND, J.M.;McREATH, 1.1981. "Estratigrafia" de rochas granitóides na região do Seridó (RN-PB), com base em critérios estruturais.Rev. Bras. Geoc., 11(1):50-57.

JARDIM DE SÁ, E.F.; MACEDO, M.H.F.; TORRES, H.H.F.; KAWASHITA, K. 1988. Geochronologyofmetaplutonicsandtheevolutionof supracrustal belts in the Borborema Province, NE Brazil. In: CONGR. LATINOAMERICANOGEOL.,7. Belém, 1988./4rt<z/.s... Belém,SBG/DNPM.p. 49-62.

KÜSTER, D. 1990. Rare-metal pegmatites of Wamba, Central Nigéria-their formation in relationship to late Pan-African granites. Mineralium Deposita, $2 S(1): 25-33$.

LETERRIER, J.; JARDIM DE SÁ, E.F.; MACEDO, M.H.F.; AMARO, V.E.
1990. Magmatic and geodynamic signature of the Brasil iano cycle plutonism in the Seridó belt,NE Brasil. In: CONGR. BRAS. GEOL, 36.Natal, 1990. Anais... Natal, SBG.j). 1640-1655.

LESQUER, A.; BELTRÂO, J.F.; ABREU, F.A.M. 1984. Proterozoic links betweenNE Brazil and West Africa: aplate tectonic model based on gravity data. Tectonophysics, 110:9-26

LIMA, E.S. 1987. Evolução termobarométrica das rochas metapelíticas da região do Seridó, Nordeste Brasileiro. Rev. Bras. Geoc., 17(3):315-323.

MACEDO, M.H.F.; JARDIM DE SÁ, E.F.; MARTINS SÁ, J. 1984. Datações $\mathrm{Rb}-\mathrm{Sr}$ em ortognaisses e a idade do Grupo Seridó. In: SIMP. GEOL. NORDESTE, 11. Natal, 1984. Atas... Natal, SBG. p. 253-262.

MARBLE, P.J. 1949. Present states of absolute ages in Brazil. Rep. Comm Measur. Geol. Time. p. 68-74.

MARTINS SÁ.J.\& LEGRAND, J.M. 1983. Superposição de fases metamórficas na região da Serra do Chico, Lages - RN. Ciências da Terra, 7:12-15.

MELLO, A. \& MELLO, Z. 1974. Metamorphic zoning in the Seridó region, Northeastern Brazil. Rev. Bras. Geoc., 4:1-14.

PESSOA, R. R. 1974. Considerações sobre a mineralogênese Pré-Cambriana do Nordeste Oriental Brasileiro. In: CONGR. BRAS. GEOL., 28. Porto Alegre, 1974.Anais... Porto Alegre, SBG. p. 3-9.

PIASECKI, M.A.J. \& VAN BREEMEN, O. 1979. A Morarian age for the'younger Moines' of Central and Western Scotland. Nature, 278:734736.

PIASECKI, M.A.J ; VAN BREEMEN, O - WRIGHT, A.E. 1981. Late Precambrian geology of Scotland, England and Wales. Mem. Can. Soc. Petrol. Geol. Alberta, 7:57-94.

PORADA, H. 1989. Pan-African rifting and orogenesis in southern to equatorial Africa and eastern Brazil. Precambrian Research, 44:103-136.

SALIM, J.; LEGRAND, J.M.; DARDENNE, M.A. 1979. Sucessão de fases de metamorfismo nos metassedimentos da região de Lages (RN). In: SIMP. GEOL. NORDESTE, 9. Natal, 1979. Atas... Natal, SBG. p. 56-63.

SCHUILING, R.D. 1967. Tin belts on the continents around the Atlantic Ocean Econ. Geol., 62:540-550.

TORQUATO, J.R. \& CORDANI, U.G. 1981. Brazil-Africa geological links. EarthSci. Rev., 17:155-176.

VAN BREEMEN, O.; PIDGEON, R.T.; JOHNSON, M.R.W. 1974. Precambrian and Palaeozoic pegmatites in the Moines of northern Scotland. J. Geol. Soc. London, 130:493-507.

MANUSCRITO A689

Recebido em 24 de janeiro de 1991 Revisão do autor em 13 de janeiro de 1992 Revisão aceita em 17 de janeiro de 1992 